ACADEMIC FREEDOM IN CANADA:

A HISTORY 
This page intentionally left blank 


\section{MICHIEL HORN}

\section{Academic Freedom in Canada: A History}

UNIVERSITY OF TORONTO PRESS

Toronto Buffalo London 
www.utppublishing.com

(1) University of Toronto Press Incorporated 1999

Toronto Buffalo London

Printed in Canada

ISBN 0-8020-0726-0

(ळ)

Printed on acid-free paper

\section{Canadian Cataloguing in Pulication Data}

Horn, Michiel, 1939-

Academic freedom in Canada : a history

Includes bibliographical references and index.

ISBN 0-8020-0726-0

1. Academic freedom - Canada - History. I. Title.

LC72.5.C3H67 $1999 \quad 378.1^{\prime 2} 21 \quad$ C98-932443-5

This book has been published with the help of a grant from the Humanities and Social Sciences Federation of Canada, using funds provided by the Social Sciences and Humanities Research Council of Canada.

University of Toronto Press acknowledges the financial assistance to its publishing program of the Canada Council for the Arts and the Ontario Arts Council. 


\section{For Cornelia}

and in memory of

Leonard Marsh (1905-1982)

Ken McNaught (1918-1997)

and

Frank Scott (1899-1985) 
This page intentionally left blank 